\title{
Prebiotics and Probiotics in Ulcerative Colitis: Where Do We Stand?
}

\author{
Gerhard Rogler
}

Division of Gastroenterology and Hepatology, University Hospital of Zurich, Zurich, Switzerland

The human gastrointestinal tract is occupied by a complex and abundant microbial community accounting for as many as $10^{13}-10^{14}$ microorganisms in the colon. This microbiota participates in a symbiotic relationship with their eukaryotic host and this partnership is viewed as essential for maintaining homeostasis. The coexistence of the host with its intestinal micriobiota is tightly controlled at various levels and an accumulating body of evidence suggests that the failure of this homeostasis is an important contribution to disease development in inflammatory bowel disease such as ulcerative colitis (UC) $[1,2]$.

According to a recent survey, 2 out of 5 patients with inflammatory bowel disease use probiotics regularly [3], therefore it is most mandatory to evaluate the potential efficacy of pre- and probiotics in UC. A recent meta-analysis by Zigra et al. [4] found 9 studies on the effects of probiotics acceptable for further analysis in the field of UC. The analyzed studies were very heterogeneous in concept and methodology. Consecutively, the results also vary among those trials. The improvement in UC activity, induction of remission and the frequency of adverse effects did not differ significantly between probiotictreated groups and control patients mainly treated with 5-aminosalicylic acid preparations [4].

Specific probiotic products have been established for the treatment of UC, such as Escherichia coli Nissle 1917 or VSL\#3 [5-8]. The latter contains 8 different strains of lactobacillae and bifidobacteriae.

E. coli Nissle is probably the best explored probiotic preparation for the treatment of UC patients [9]. Other bacterial species are less well explored. In addition, the combination of a probiotic together with a prebiotic substance (a so-called symbiotic preparation) has rarely been studied [10]. Therapy with E. coli Nissle for maintenance of remission of UC is now recommended in several European guidelines on the treatment of UC [11]. In this issue of Digestion, Ishikawa and co-workers investigated the effect of bifidobacteria in patients with ulcerative colitis (Beneficial Effects of Probiotic Bifidobacterium and Galacto-oligosaccharide in Patients with Ulcerative Colitis: A Randomized Controlled Study). They had previously found that bifidobacteria-fermented milk containing live Bifidobacterium was effective in maintaining remission in UC patients and also in treating patients with mild to moderately active UC [12]. The latter study was a randomized placebo-controlled trial. However, such bifidobacteria-fermented milk not only contains live bacteria but also their metabolic products, making it difficult to decide whether the bacteria itself is anti-inflammatory or whether these metabolic products can downregulate inflammation. This illustrates another difficulty in pre-/ pro-/synbiotic studies: it remains unclear whether the live bacteria are necessary for a clinical effect of metabolic

\section{KARGER}

Fax +4161306 1234 E-Mail karger@karger.ch www.karger.com
(C) 2011 S. Karger AG, Basel 0012-2823/11/0842-0126\$38.00/0

Accessible online at: www.karger.com/dig
Gerhard Rogler, MD, PhD

Division of Gastroenterology and Hepatology

Department of Internal Medicine, University Hospital of Zurich

Rämistrasse 100, CH-8091 Zurich (Switzerland)

E-Mail gerhard.rogler@usz.ch 
products of such a bacterial strain which would be easier to apply and would induce a similar effect. As a number of studies have shown that supernatants of bacterial cultures also generate similar effects, this question certainly is valid [13-15].

The present study by Ishikawa and co-workers does not answer this question either. The authors chose a synbiotic approach adding a probiotic to the probiotic tested earlier. Patients were randomized to either the synbiotic treatment or a control group with standard care. The authors found a significant difference in endoscopic improvement as compared to the control group after 1 year of treatment. The study again underlines the potential beneficial effect biotics can have in patients with UC. They suggest a large-scale randomized placebo-controlled study. However, the important questions discussed above are still open: Do we need live bacteria? Could bacterial metabolic products also be effective? And does the synbiotic preparation provide any advantage over a simply probiotic preparation. If the authors plan a large study it would be of great interest to not only include the two study arms as in the clinical trial presented. A further study arm with only the bifidobacteria would allow comparison with the synbiotic preparation and provide information whether the prebiotic is needed at all. An additional study arm with only the prebiotic would tell us whether we need the bifidobacteria at all or whether such a prebiotic can change the colonic flora in a way described by the authors (reduction of Bacteroides alone) without the need of an additional probiotic. As mentioned, these are important questions which need to be answered in future studies.

\section{Disclosure Statement}

The author discloses grant support from Abbot, Ardeypharm, Essex, FALK, Flamentera, Novartis, Tillots, UCB and Zeller.

\section{References}

1 Tannock GW: The bowel microbiota and inflammatory bowel diseases. Int J Inflam 2010;2010:954051.

$\checkmark 2$ Nell S, Suerbaum S, Josenhans C: The impact of the microbiota on the pathogenesis of IBD: lessons from mouse infection models. Nat Rev Microbiol 2010;8:564-577.

3 Joos S, Rosemann T, Szecsenyi J, Hahn EG, Willich SN, Brinkhaus B: Use of complementary and alternative medicine in Germany a survey of patients with inflammatory bowel disease. BMC Complement Altern Med 2006;6:19.

$\checkmark 4$ Zigra PI, Maipa VE, Alamanos YP: Probiotics and remission of ulcerative colitis: a systematic review. Neth J Med 2007;65:411-418.

5 Do VT, Baird BG, Kockler DR: Probiotics for maintaining remission of ulcerative colitis in adults. Ann Pharmacother 2010;44:565-571.

6 Schultz M: Clinical use of E. coli Nissle 1917 in inflammatory bowel disease. Inflamm Bowel Dis 2008;14:1012-1018.

7 Seksik P, Dray X, Sokol H, Marteau P: Is there any place for alimentary probiotics, prebiotics or synbiotics, for patients with inflammatory bowel disease? Mol Nutr Food Res 2008; 52:906-912.
-8 Chapman TM, Plosker GL, Figgitt DP: VSL\#3 probiotic mixture: a review of its use in chronic inflammatory bowel diseases. Drugs 2006;66:1371-1387.

-9 Kruis W, Fric P, Pokrotnieks J, Lukas M, Fixa B, Kascak M, Kamm MA, Weismueller J, Beglinger C, Stolte M, Wolff C, Schulze J: Maintaining remission of ulcerative colitis with the probiotic Escherichia coli Nissle 1917 is as effective as with standard mesalazine. Gut 2004;53:1617-1623.

10 Federico A, Tuccillo C, Grossi E, Abbiati R, Garbagna N, Romano M, Tiso A, Del Vecchio Blanco C, Loguercio C: The effect of a new symbiotic formulation on plasma levels and peripheral blood mononuclear cell expression of some pro-inflammatory cytokines in patients with ulcerative colitis: a pilot study. Eur Rev Med Pharmacol Sci 2009; 13:285-293.

11 Stange EF, Travis SP: The European consensus on ulcerative colitis: new horizons? Gut 2008;57:1029-1031.

12 Ishikawa H, Akedo I, Umesaki Y, Tanaka R, Imaoka A, Otani T: Randomized controlled trial of the effect of bifidobacteria-fermented milk on ulcerative colitis. J Am Coll Nutr 2003;22:56-63.
13 Jensen GS, Benson KF, Carter SG, Endres JR: GanedenBC30 cell wall and metabolites: anti-inflammatory and immune modulating effects in vitro. BMC Immunol 2010;11:15.

14 Watanabe T, Nishio H, Tanigawa T, Yamagami $\mathrm{H}$, Okazaki $\mathrm{H}$, Watanabe $\mathrm{K}$, Tominaga K, Fujiwara Y, Oshitani N, Asahara T, Nomoto K, Higuchi K, Takeuchi K, Arakawa T: Probiotic Lactobacillus casei strain Shirota prevents indomethacin-induced small intestinal injury: involvement of lactic acid. Am J Physiol Gastrointest Liver Physiol 2009; 297:G506-G513.

15 Sokol H, Pigneur B, Watterlot L, Lakhdari O, Bermudez-Humaran LG, Gratadoux JJ, Blugeon S, Bridonneau C, Furet JP, Corthier G, Grangette C, Vasquez N, Pochart P, Trugnan G, Thomas G, Blottiere HM, Dore J, Marteau P, Seksik P, Langella P: Faecalibacterium prausnitzii is an anti-inflammatory commensal bacterium identified by gut microbiota analysis of Crohn disease patients. Proc Natl Acad Sci USA 2008;105:16731-16736. 